\title{
Preconditioning strategies to prevent acute kidney injury
}

\section{[version 1; peer review: 2 approved]}

\author{
Martin Richard Späth (iD1,2, Felix Carlo Koehler1,2, Karla Johanna Ruth Hoyer-Allo1,2, \\ Franziska Grundmann1, Volker Burst ${ }^{1}$, Roman-Ulrich Müller (Di) 1,2
}

\begin{abstract}
${ }^{1}$ Department II of Internal Medicine and Center for Molecular Medicine Cologne, University of Cologne, Faculty of Medicine and University Hospital Cologne, Cologne, NRW, 50937, Germany

${ }^{2}$ Cologne Excellence Cluster on Cellular Stress Responses in Aging-Associated Diseases, University of Cologne, Cologne, NRW, 50931, Germany
\end{abstract}

\section{V1 First published: 03 Apr 2020, 9(F1000 Faculty Rev):237 \\ https://doi.org/10.12688/f1000research.21406.1}

Latest published: 03 Apr 2020, 9(F1000 Faculty Rev):237

https://doi.org/10.12688/f1000research.21406.1

\section{Abstract}

Acute kidney injury is a common clinical disorder resulting in significantly increased morbidity and mortality. However, despite extensive research, strategies for prevention or treatment are still lacking in routine clinical practice.

Already decades ago, several preconditioning strategies (e. g. ischemic/hypoxic preconditioning and calorie restriction) have been published and their extraordinary effectiveness - especially in rodents - has raised the hope for powerful clinical tools to prevent acute kidney injury. However, the underlying mechanisms are still not completely understood and translation to the clinics has not been successful yet. In this review, the most attractive strategies and the current mechanistic concepts are introduced and discussed. Furthermore, we present clinical trials evaluating the feasibility of preconditioning in the clinical setting.

\section{Keywords}

acute kidney injury, AKI, preconditioning, hypoxia, hypoxic preconditioning, RIPC, ischemic preconditioning, diet, dietary restriction, caloric restriction, protein restriction, fasting, contrast induced nephropathy, cardiopulmonary bypass

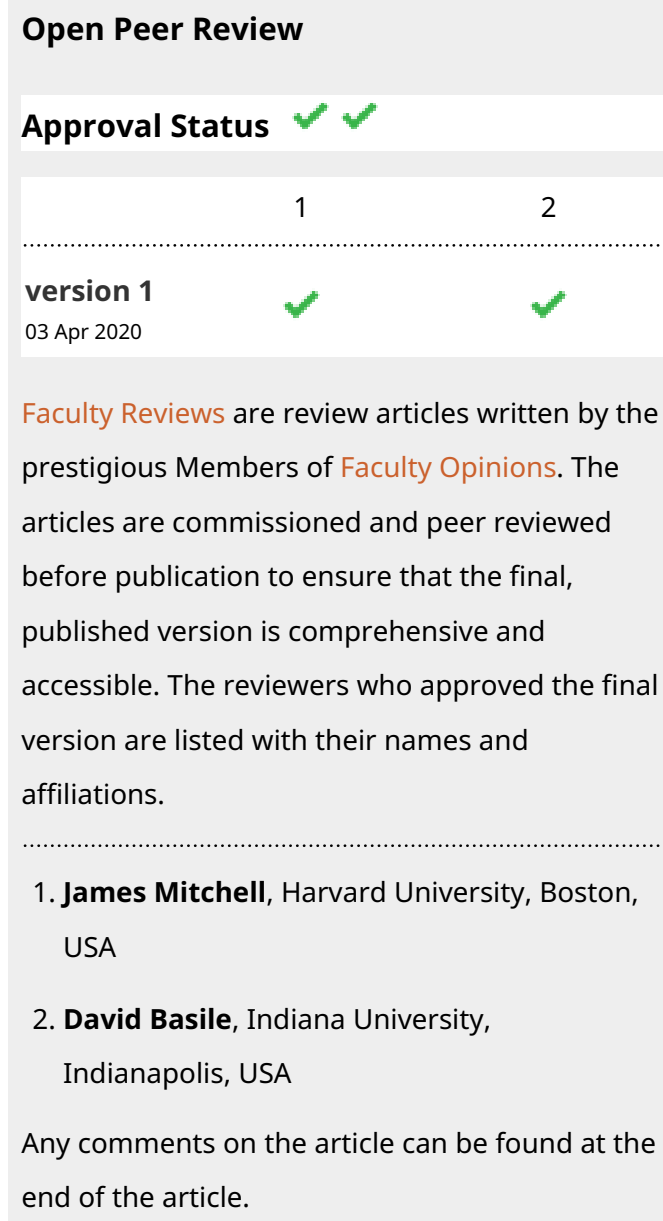

1 2

version 1

03 Apr 2020

Faculty Reviews are review articles written by the prestigious Members of Faculty Opinions. The articles are commissioned and peer reviewed before publication to ensure that the final, published version is comprehensive and accessible. The reviewers who approved the final version are listed with their names and affiliations.

1. James Mitchell, Harvard University, Boston, USA

2. David Basile, Indiana University, Indianapolis, USA

Any comments on the article can be found at the end of the article. 
Corresponding author: Roman-Ulrich Müller (roman-ulrich.mueller@uk-koeln.de)

Author roles: Späth MR: Writing - Original Draft Preparation, Writing - Review \& Editing; Koehler FC: Writing - Review \& Editing; HoyerAllo KJR: Writing - Review \& Editing; Grundmann F: Writing - Review \& Editing; Burst V: Conceptualization, Supervision, Writing Review \& Editing; Müller RU: Conceptualization, Funding Acquisition, Project Administration, Supervision, Writing - Review \& Editing

Competing interests: The Department II of Internal Medicine, with which all of the authors are affiliated, received funds from Bayer AG and Fresenius Kabi to support research projects.

Grant information: MRS is supported by the Koeln Fortune program/Faculty of Medicine, University of Cologne. FCK is supported by the Koeln Fortune program/Faculty of Medicine, University of Cologne and has received grants from the German Federal Ministry of Research and Education and non-financial support from Miltenyi Biotec GmbH (Bergisch Gladbach, Germany) outside the submitted work. R-UM is supported by the Nachwuchsgruppen.NRW program of the Ministry of Science North Rhine Westfalia (MIWF) (to R-UM). The funders had no role in study design, data collection and analysis, decision to publish, or preparation of the manuscript.

Copyright: @ 2020 Späth MR et al. This is an open access article distributed under the terms of the Creative Commons Attribution License, which permits unrestricted use, distribution, and reproduction in any medium, provided the original work is properly cited.

How to cite this article: Späth MR, Koehler FC, Hoyer-Allo KJR et al. Preconditioning strategies to prevent acute kidney injury [version 1; peer review: 2 approved] F1000Research 2020, 9(F1000 Faculty Rev):237 https://doi.org/10.12688/f1000research.21406.1

First published: 03 Apr 2020, 9(F1000 Faculty Rev):237 https://doi.org/10.12688/f1000research.21406.1 


\section{Introduction}

Acute kidney injury (AKI) is a highly relevant problem in clinical practice and is associated with an increased risk of mortality ${ }^{1,2}$, the development of chronic kidney disease, and cardiovascular events ${ }^{3,4}$. The incidence of AKI has increased in recent years, and, in the context of the demographic change, it is likely that a plateau has not been reached yet ${ }^{5,6}$.

Imbalances between circulatory demands and perfusion leading to renal ischemia as well as toxic insults are frequent causes of AKI and are often observed as adverse events of medical interventions (for example, major surgery or chemotherapy). In both cases, loss of cell adhesion molecules, cell polarity, and death of tubular epithelial cells lead to cell detachment with subsequent urinary tract dysfunction ${ }^{7}$. Intensive monitoring and adequate fluid management at the time of diagnosis constitute the standard therapy. However, an effective treatment for established AKI is still missing. Apart from maintaining euvolemia, atraumatic/minimally invasive surgical techniques, and avoidance of potentially nephrotoxic substances, no preventive measures have been proven to exert a protective benefit in clinical practice ${ }^{8}$.

Animal models have been established for both types of AKI primarily using rodents and employing ischemia-reperfusion injury (IRI) by transient clamping of the renal vessels ${ }^{9-11}$ or toxic tubular injury induced by the intraperitoneal injection of cisplatin $^{12-14}$. In both models, various preconditioning algorithms have proven to be very effective. In general, the term "preconditioning" describes the strategy of activating the body's own stress resistance mechanisms, thereby mitigating consecutive harm $^{15}$, and commonly exploits the concept of hormesis.

In this review article, we discuss known and effective strategies of preconditioning. Considering promising results from animal models and first results in clinical trials, we will focus on strategies targeting either the cellular response to hypoxia or nutrient availability: ischemic preconditioning (IPC) $)^{16}$, remote IPC (RIPC) $)^{17}$, hypoxic preconditioning (HP) ${ }^{18}$, prolyl-hydroxylase (PHD) inhibition (PHDi) ${ }^{19}$, and dietary interventions ${ }^{9}$.

\section{Ischemic preconditioning}

The oldest known procedure is IPC: repetitive periods of short-term sublethal organ ischemia enhance the resistance against cellular stress and mitigate the damage of subsequent profound ischemic injury ${ }^{16}$. The underlying mechanisms have not been fully deciphered yet. So far, it has been assumed that the repetitive stimuli lead to a release of various chemical messengers (for example, calcium ions, reactive oxygen species, and hydrogen sulfide), vasoactive substances (for example, adenosine, bradykinin, opioids, and urocortins), neurotransmitters and hormones (for example, acetylcholine and angiotensin) as well as cytokines (for example, tumor necrosis factor-alpha $[\mathrm{TNF}-\alpha]$, interleukin-6, and prostaglandins) activating $\mathrm{G}$ protein-coupled receptors ${ }^{20,21}$. A number of pathways have been implicated to be involved downstream of these mediators. First is the activation of nitric oxide (NO) and NO synthase (NOS) by activation of protein kinase $\mathrm{C}$ (PKC), phosphoinoside 3 kinase (PI3K/Akt), and the guanylatcyclase leading to the activation of ATP-dependent potassium channels $\left(\mathrm{K}_{\text {ATP }}\right)$ and the priming of mitochondrial permeability transition pore $(\mathrm{MPTP})^{20,22-26}$. Second is the reperfusion injury salvage kinase (RISK) pathway by activation of PI3K/Akt, 70 ribosomal protein S6 kinase (p70S6K), glycogen synthase kinase 3b (GSK3b), and the inhibition of MPTP opening ${ }^{20,21,26-29}$. Third, the survival activating factor enhancement (SAFE) pathway gets activated by activation of glycoprotein 130 (gp130) or TNF- $\alpha$ receptors, the Janus-activated kinase (JAK) signal transducer, and the stimulation of the activator of transcription (STAT) $20,21,26,29-31$. Furthermore, a role for SIRT1-mediated $\mathrm{NAD}^{+}$-dependent deacetylation $^{32}$ and mitochondrial biogenesis ${ }^{33}$ has recently been shown.

\section{Remote ischemic preconditioning}

Although IPC shows promising results in animal models and clinical pilot trials, it is obvious that translation to the clinical setting is restricted to surgical settings and therefore is not easily feasible. Consequently, aiming to exploit similar mechanisms, the strategy of RIPC was developed. Through RIPC, an organ (for example, the heart) can be protected from damage by applying repetitive short-term sublethal periods of ischemia to a remote tissue (for example, the kidney) ${ }^{34}$. This protection goes along with a gene regulatory effect in the target organ ${ }^{35}$. Several different mediators of this distant effect have been hypothesized in the past: on the one hand, a neuronal effect in which the afferent neurons of the preconditioned organ provide protection of the remote organ has been described ${ }^{36}$. On the other hand, a humoral effect by various mediators has been described in several publications and the actual key candidates remain elusive. More recently, a very elegant study using the ischemia-reperfusion model of the heart could show that activation of hypoxia signaling in skeletal muscles increases the production of alpha-ketoglutarate (alphaKG). Circulating alphaKG induces kynurenic acid (KYNA) formation in the liver, and KYNA itself was sufficient to protect the heart from ischemic injury ${ }^{37}$. Furthermore, a humoral activation of various cellular pathways (for example, by $\mathrm{NO}^{38}$, connexin $43^{39}$, or hypoxia-inducible factor 1 alpha $[\mathrm{HIF}-1 \alpha]^{40}$ ) has been published. The major advantage of RIPC lies in its simple clinical applicability since the remote effect can also be achieved by repetitive inflation of a blood pressure cuff on the arm or thigh. In a randomized, double-blind, sham-controlled clinical trial investigating the effect of RIPC prior to elective coronary angiography, a significant reduction of the incidence of contrast media-induced acute injury (defined as an increment of serum creatinine of at least $0.5 \mathrm{mg} / \mathrm{dL}$ or a relative increase of more than $25 \%$ over baseline value within 48 hours) could be shown for the intervention group in a cohort of 100 patients with chronic kidney disease (that is, serum creatinine of more than $1.4 \mathrm{mg} / \mathrm{dL}$ or estimated glomerular filtration rate [eGFR] of less than $60 \mathrm{~mL} / \mathrm{min} * 1.73 \mathrm{~m}^{2}$ ) and at high risk of developing contrast medium-induced kidney injury according to the Mehran risk score $^{41}$. In another randomized, prospective, multicenter, and double-blind clinical trial investigating 222 patients with a reduced eGFR (that is, $<40 \mathrm{~mL} / \mathrm{min}$ per $1.73 \mathrm{~m}^{2}$ or between 40 and $60 \mathrm{~mL} / \mathrm{min}$ per $1.73 \mathrm{~m}^{2}$ ) and two or more risk factors (age $\geq 75$ years, diabetes mellitus, or heart failure New York Heart Association [NYHA] III or IV) undergoing 
elective coronary angiography or percutaneous translumial coronary angioplasty (or both), no significant difference for any study group could be shown regarding the incidence of contrast media-induced nephropathy (primary endpoint), change of serum creatinine, or change of eGFR (secondary endpoints $)^{42}$. The comparability of both studies is limited because the population of the latter trial included fewer patients with diabetes mellitus ( $\sim 50$ to $\sim 62 \%$, respectively) and the Mehran score differed markedly ( $~ 8$ to 13$)$. Besides, the incidence of contrast media-induced nephropathy in the control group of the trial by Roubille et al. $^{42}$ was reduced in comparison with their own database (4.5 to 28\%) and in comparison with the trial by Er et al. ${ }^{41}$ (20\%). Furthermore, the volume of contrast media used was much smaller in the trial by Roubille et al. ${ }^{42}(\sim 75 \mathrm{~mL})$ in comparison with the trial by Er et al $^{41}(\sim 120 \mathrm{~mL})$.

In addition, the clinical relevance of contrast-induced nephropathy (CIN) has been debated extensively in recent years, supporting the idea that its incidence is far overrated in clinical practice; this, in turn, limits the value of the used model ${ }^{43}$. The largest trials examining the protective potential of RIPC were performed in cohorts undergoing surgery on cardiopulmonary bypass. Unfortunately, owing to major differences in both outcome and patient characteristics, these studies, in line with the data on CIN, have not provided conclusive results. Zarbock et al. conducted a prospective randomized, double-blind, and sham-controlled multicenter trial enrolling 240 patients who underwent cardiac surgery with the use of cardiopulmonary bypass $^{44}$. RIPC led to a lower incidence of AKI (primary endpoint), a reduced need for renal replacement therapy (RRT), and a shorter length of stay in the intensive care unit (ICU). These results were highly promising at first; however, two much larger randomized, double-blind trials published in 2015 dampened the enthusiasm. The RIPHEART trial examined RIPC in 1403 subjects undergoing coronary artery bypass graft (CABG) surgery and did not detect any benefit concerning the primary endpoint (death, myocardial infarction, stroke, AKI, or length of stay in the ICU) ${ }^{45}$. The same holds true for the ERICCA trial $^{46}$. Here, RIPC did not result in improved resistance to cardiovascular and cerebrovascular events within 12 months after surgery (primary endpoint) and perioperative myocardial infarction, acute myocardial infarction, AKI, length of stay on the ICU, ejection fraction, and quality of life (secondary endpoints) in 1612 patients after CABG with or without cardiac valve surgery (801 RIPC and 811 sham). An important aspect that has been discussed to explain some of the differences between these trials is the different mode of anesthesia that may interfere with the potential of RIPC. In ERICCA, the anesthetic procedure was not standardized ${ }^{46}$ whereas it was limited to inhalation anesthesia in Zarbock et al. and intravenous anesthesia using propofol in RIPHEART. Furthermore, Zarbock et al. explicitly enrolled only individuals at a high risk of AKI defined by a Cleveland Clinic Foundation score of 6 or higher. In RIPHEART, there was no stratification for the risk of AKI and the participants showed a moderate risk for death 30 days after surgery (mean Logistic EuroSCORE ${ }^{47,48}$ for both groups: 4.2). In ERICCA, patients were eligible only with a EuroSCORE of 5 or higher without any specific risk assessment for AKI. In a meta-analysis of RIPC in the prevention of AKI in patients undergoing CABG surgery, a benefit of this pre-treatment could be demonstrated only in the subgroup that received inhalation anesthesia. Here, it is important to note that volatile anesthetics themselves are being discussed as preconditioning agents ${ }^{49,50}$. Nonetheless, RIPC appeared to have a potential additive effect to this protective potential in this study. With regard to the development of dialysis-dependent kidney injury, there was no advantage in any of the subgroups examined $^{51}$. From the perspective of the authors, owing to the different risk stratification in the selection of subjects and non-uniform operating procedures, a final assessment regarding the potential of RIPC in the clinical setting is currently not possible.

\section{Hypoxic preconditioning and prolyl-hydroxylase inhibition}

Although for a couple of years the field focused on driving RIPC toward a potential clinical use, other modes of preconditioning have regained increasing attention more recently. In 1994, a model for HP was published ${ }^{52}$. Six-day-old rats that were preconditioned by subjecting them to an ambient oxygen content of $8 \%$ for 3 hours showed significantly reduced cerebral infarct zones following unilateral occlusion of the carotid artery $^{52}$. Altered HIF signaling could be identified as a mediator of this effect ${ }^{18}$. Even though HP, like IPC, cannot be directly transferred to the clinical setting, activation of HIF can be induced pharmacologically, allowing potential future interventions in the patient setting. HIFs are heterodimeric proteins consisting of a hypoxia-regulated HIF- $\alpha$ and a constitutive HIF- $\beta$ subunit ${ }^{53}$. Under normoxia, PHDs hydroxylate specific proline residues of the HIF- $\alpha$ subunit, inducing its proteasomal degradation. Hypoxia inhibits PHDs and allows the nuclear accumulation of HIF- $\alpha$ where the assembly of dimers of $\alpha$ - and $\beta$-subunit leads to the transcription of numerous target genes that have been hypothesized to be involved in the protective effect (for example, erythropoietin, vascular endothelial growth factor [VEGF], and heme oxygenase- 1$)^{54,55}$. PHD inhibitors are available and have been shown to mediate a protective effect regarding renal IRI comparable to HP using a rat model ${ }^{19}$. Interestingly, in the meantime, a PHD inhibitor-roxadustat-has been approved for the treatment of anemia in patients with dialysis-dependent and non-dialysis-dependent chronic kidney disease in China ${ }^{56-58}$ and Japan. More data on roxadustat were recently presented at Kidney Week ${ }^{59-61}$ aiming at approval for the US and Europe. Additionally, various other PHD-inhibiting compounds are being tested in clinical trials ${ }^{53}$. A double-blind, randomized, single-center phase II trial (ClinicalTrials.gov Identifier: NCT01920594) investigating a possible reduction in neurological, renal, or cardiac ischemia (or a combination of these) by PHDi prior to elective aortic aneurysm surgery has been completed but not fully published yet.

\section{Caloric restriction}

Apart from targeting the cellular response to hypoxia, dietary interventions have been shown to be one of the most promising strategies in organoprotection. Calorie restriction (CR) has long been known to mediate life-span extension, a finding that was first demonstrated in a rat model in $1935^{62}$ and confirmed in 
various different species, including primates ${ }^{63}$. Importantly, as known for many longevity-inducing interventions, CR leads to a profound and conserved increase in organismal and cellular stress resistance ${ }^{64,65}$. More recent work could show that changes in nucleolar biology are a shared mechanism of several life span-extending interventions with $\mathrm{CR}$ inducing a significant reduction in nucleolar size in Caenorhabditis elegans, fruit flies, mice, and humans ${ }^{66}$. Importantly, nucleolar size early in life was also predictive of life span in the nematode model. Regarding the kidney, Mitchell et al. could show that a short-term reduction in food intake (to $70 \%$ ) protected against murine renal IRI 9 Improved insulin sensitivity and reduced insulin/IGF-1 signaling and increased expression of antioxidant defense enzymes were hypothesized to be among the key mechanisms for protection against renal and hepatic IRI as well as genotoxic or chemotherapeutic stress ${ }^{9,67-69}$. Recently, it was shown that the CR-mediated improvement of insulin sensitivity is mediated by mTORC2 signaling. However, disruption of mTORC2 signaling inducing insulin resistance in a Rictor knockout mouse model did not diminish the increase of fitness and life $\operatorname{span}^{70}$, indicating a potential mechanistic difference in longevity and stress resistance. Although the CR-mediated protective effect has been published in several mammals, effectiveness in humans has not yet been clearly demonstrated ${ }^{71,72}$. Yet there is first evidence of feasibility and potential efficacy in humans. The safety of a preoperative calorie- and protein-restricted diet in healthy kidney donors and obese patients undergoing bariatric surgery was shown by Jongbloed et al. ${ }^{73}$. Furthermore, feasibility was addressed in living kidney donors ${ }^{74}$. A large-scale trial investigating permissive underfeeding compared with standard enteral feeding in critically ill patients demonstrated a significantly lower rate of RRT in the group with a calorie-restricted enteral feeding protocol ${ }^{11,72}$. Recently, we studied the effects of a 7-day preoperative $\mathrm{CR}$ on renal function in a randomized controlled clinical trial ${ }^{75}$. Eighty-two patients at risk for post-surgery AKI were randomly assigned 1:1 to receive either a formula diet containing $60 \%$ of their daily energy requirement or ad libitum food for 7 days prior to elective cardiac surgery involving cardiopulmonary bypass. Although $\mathrm{CR}$ had no impact on the primary endpoint (the increase of serum creatinine at 24 hours after cardiac surgery), there was a significant between-group difference with a favorable effect of $\mathrm{CR}$ on creatinine kinetics at 48 hours and at discharge. Additional subgroup analyses suggested that the positive effect appeared to be most prominent in men and obese individuals with a body mass index of more than $25 \mathrm{~kg} / \mathrm{m}^{275}$. In parallel, a second randomized controlled clinical trial for preventing AKI in patients undergoing percutaneous coronary intervention was performed to determine the feasibility and effectiveness of pre-interventional CR. As in the above-mentioned trial, patients were randomly assigned either to receive a formula diet containing $60 \%$ of their calculated daily energy expenditure or to ad libitum food intake. Again, beneficial effects were detected only in post-hoc subgroup analyses ${ }^{76}$. Although the findings of these clinical trials did not reflect the effects of $\mathrm{CR}$ seen in animal experiments, the studies could show that the intervention is safe and feasible even in a morbid patient population. The fact that the magnitude of the observed effects is smaller than in the rodent models may be due to several aspects. It is still unknown how long a diet must be applied in humans, how much the caloric content has to be restricted, and how the most potent dietary regimen should be designed ${ }^{75}$. Given these caveats of implementing $\mathrm{CR}$ in the clinical setting, it is extremely important to have a better understanding of both the molecular mechanisms underlying CR-mediated organoprotection and the ideal dietary interventions to obtain these effects. From the authors' point of view, this is necessary in order to further develop targeted approaches (for example, by drugs or targeted dietary interventions) for improving feasibility and effect size in a clinical setting.

\section{Protein restriction}

There is ample evidence that CR does not mediate stress resistance through mere reduction of calories, and several other dietary interventions that modulate specific dietary components have shown beneficial effects in organ injury. Here, protein restriction (PR) is an important example, and $\mathrm{PR}$ has been demonstrated to confer additive effects to $\mathrm{CR}^{77}$. Interestingly, restriction of any single essential amino acid appears to be sufficient to mediate systemic adaptive responses leading to metabolic benefits ${ }^{78-80}$. Regarding renal organ protection, an important aspect was highlighted by a study published in 2015 showing that PR (with identical calorie intake in both groups) prior to hepatic IRI caused strong protective effects similar to those of $\mathrm{CR}$ and that these positive effects could be reversed by the addition of sulfur-containing amino $\operatorname{acids}^{81,82}$. Mechanistically, restriction of sulfur-containing amino acids caused an increase of hydrogen sulfide $\left(\mathrm{H}_{2} \mathrm{~S}\right)$ formation by activation of the transsulfuration pathway ${ }^{81}$ and addition of $\mathrm{H}_{2} \mathrm{~S}$ induced cellular stress resistance ${ }^{83-85}$. Hence, both $\mathrm{H}_{2} \mathrm{~S}$ donors (for example, $\mathrm{MESNA}^{86}$ ) and diets reduced in sulfur-containing amino acid intake ${ }^{87}$ may be future strategies to transfer the potential of CR to the patient setting. A clinical trial (ClinicalTrials.gov Identifier: NCT03715868) investigating a non-dairy (significantly reduced in sulfur amino acids) formula diet prior to cardiac surgery was recently initiated at our center.

\section{Fasting-mimicking and ketogenic diets}

Intermittent or periodic fasting enables the activation of cellular signal transduction similar to that of $\mathrm{CR}$ with preserved nourishment ${ }^{8}$. Fasting-mimicking diets (FMDs) are a tool to reach comparable effects, and their safety and feasibility have been proven in several phase I and phase II studies ${ }^{89-91}$. Mechanistically, FMD results in cellular and metabolic effects similar to those of $\mathrm{CR}$, including improved glucose homeostasis and insulin sensitivity, as well as improved cellular stress adaptation $^{89,92}$ (for example, by modulation of the mechanistic target of rapamycin [mTOR] pathway ${ }^{93}$ ). It will be interesting to see whether these approaches have a role in organoprotection as well.

mTOR is an evolutionary conserved protein kinase orchestrating growth and metabolism. By inducing autophagy and by the reduction of protein translation leading to decreased proteotoxic and oxidative stress, mTOR inhibition results in cellular stress resistance ${ }^{94,95}$. mTOR is regulated through nourishment, and dietary inhibition of the mTOR pathway can be achieved either by restriction of the branched chain amino acids (BCAAs) 
valine, leucine, and isoleucine or by changes in the ratio of macronutrients replacing proteins with carbohydrates ${ }^{96-98}$. Increased exposure to BCAA is associated with hyperphagia, obesity, insulin resistance, and mortality ${ }^{99-101}$. Additionally, a protein-to-carbohydrate ratio of 0.07 resulting in low-protein and high-carbohydrate diet leads to improved stress resistance, health, and life $\operatorname{span}^{82,98,102}$. Strikingly, low-sugar diets also revealed beneficial effects on health and life span in C. elegans ${ }^{103}$. On the other hand, glucose supplementation did not interfere with fasting-induced renal protection in the ischemia-reperfusion mouse model ${ }^{104}$. Because the optimal diet for humans in the context of organ protection remains unknown, there is much room for improvement. Here, clarification whether reduction of specific amino acids or the changes in ratio of the macronutrients are the key drivers to improve metabolism, fitness and health in humans will be required.

Ketogenic diets are high in fat and very low in carbohydrates and result in synthesis of ketone bodies and exceeding $\beta$-oxidation of fatty acids. Similar to $\mathrm{CR}$, ketogenic diets extend the life span in rodents with preserved physiological functions but do not lead to malnourishment ${ }^{105}$. Ketone bodies, such as $\beta$ hydroxybutyrate, suppress oxidative stress, resulting in nephroprotection $^{106}$. Owing to their additional neuroprotective effects, ketogenic diets have been proven to be feasible and safe in medical use in human pharmacoresistant epilepsy ${ }^{107}$. Given that
$\mathrm{CR}$ in rodents actually does induce ketogenesis because of the nature of the feeding cycles ${ }^{108}$, ketogenic diets may be another promising strategy to ameliorate AKI in a clinical setting.

\section{Summary}

Taken together, recent experiments in animal models have helped to increase our understanding of preconditioning in AKI (see Figure 1), although clear-cut clinical effectiveness in humans has not been proven yet. Consequently, dietary interventions that have been tested to date in humans will probably not solve the problem. Nonetheless, given the tremendous effects in animal models in combination with the unmet clinical need, such research is of high importance. Direct pharmacological or optimized tailored dietary targeting of the molecular players may be the more straightforward approach in humans but will not be possible without detailed knowledge of the molecular mechanisms. Given that different modes of preconditioning are potentially based on similar mechanisms, comparative analyses may have a significant added value. In a recent study on HP and $\mathrm{CR}$ in the mouse model of cisplatin-induced kidney injury using an integrative analysis of transcriptomics, proteomics, and N-degradomics, we found that mRNA expression only moderately predicted protein expression. But the more the mRNA and the proteome dissociated, the higher was the serum creatinine in the individual animal. N-degradomic studies revealed extracellular, specific proteolytic complement activation

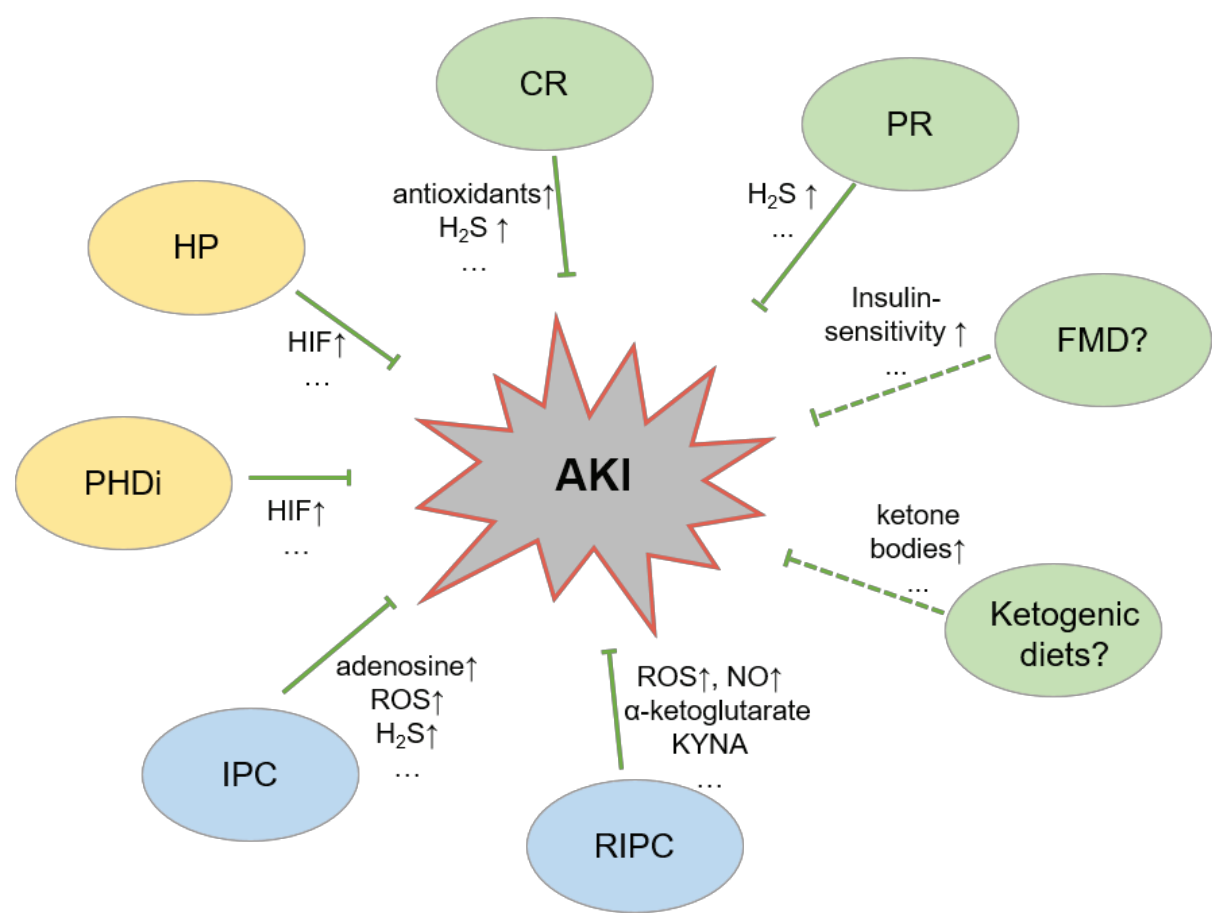

Figure 1. Schematic illustration of the mechanisms involved in various preconditioning strategies. The different modes of preconditioning have been shown, or are supposed, to alleviate acute kidney injury by production of chemokines or metabolites. AKI, acute kidney injury; $\mathrm{CR}$, calorie restriction; FMD, fasting-mimicking diet; H2S, hydrogen sulfide; HIF, hypoxia-inducible factor; HP, hypoxic preconditioning; IPC, ischemic preconditioning; KYNA, kynurenic acid; PHDi, prolyl-hydroxlase inhibition; PR, protein restriction; RIPC, remote ischemic preconditioning; ROS, reactive oxygen species. Bar-headed lines indicate inhibition, dashed lines and question marks indicate hypotheses, "..." indicates that not all mediators are displayed, and $\uparrow$ indicates increase. 
that can be alleviated by these two preconditioning methods ${ }^{12}$; this is in line with results of other groups showing that protease inhibition is a potential therapeutic approach ${ }^{109,110}$. Further studies comparing two different modes of preconditioning (HP-CR and HP-PHDi) in murine renal IRI models are being carried out, revealing shared mechanisms reflected by overlapping pathways and common regulation of target genes in association with the clinical outcome by integrative multi-omics approaches ${ }^{111,112}$. Numerous other basic scientific and clinical studies on these procedures are under way. This improved knowledge of the molecular mechanisms involved will be crucial to translate future protective strategies into the clinical setting (for example, using targeted pharmacological approaches).

\section{Abbreviations}

alphaKG, $\alpha$-ketoglutarate; AKI, acute kidney injury; BCAA, branched chain amino acid; CABG, coronary artery bypass graft; CIN, contrast-induced nephropathy; CR, calorie restriction; eGFR, estimated glomerular filtration rate; FMD, fasting-mimicking diet; $\mathrm{H}_{2} \mathrm{~S}$, hydrogen sulfide; HIF, hypoxia-inducible factor; HP, hypoxic preconditioning; ICU, intensive care unit; IPC, ischemic preconditioning, IRI, ischemia-reperfusion injury; KYNA, kynurenic acid; MPTP, mitochondrial permeability transition pore; mTOR, mechanistic target of rapamycin; NO, nitric oxide; PHD, prolyl-hydroxylase; PHDi, prolyl-hydroxylase inhibition; PI3K, phosphoinoside 3 kinase; PR, protein restriction; RIPC, remote ischemic preconditioning; RRT, renal replacement therapy; TNF- $\alpha$, tumor necrosis factor-alpha
1. $\mathrm{F}$ Oppert M, Engel C, Brunkhorst FM, et al.: Acute renal failure in patients with severe sepsis and septic shock--a significant independent risk factor for mortality: Results from the German Prevalence Study. Nephrol Dial Transplant 2008; 23(3): 904-9.

PubMed Abstract | Publisher Full Text | F1000 Recommendation

2. Susantitaphong $\mathrm{P}$, Cruz DN, Cerda J, et al:: World Incidence of AKI: A Meta-Analysis. Clin J Am Soc Nephrol. 2013; 8(9): 1482-93. PubMed Abstract | Publisher Full Text | Free Full Text

3. Leung KCW, Tonelli M, James MT: Chronic kidney disease following acute kidney injury-risk and outcomes. Nat Rev Nephrol. 2013; 9(2): 77-85. PubMed Abstract | Publisher Full Text

4. Lim CC, Tan CS, Chia CM, et al:: Long-Term Risk of Progressive Chronic Kidney Disease in Patients with Severe Acute Kidney Injury Requiring Dialysis after Coronary Artery Bypass Surgery. Cardiorenal Med. 2015; 5(3): 157-63. PubMed Abstract | Publisher Full Text | Free Full Text

5. Hsu Cy, McCulloch CE, Fan D, et al.: Community-based incidence of acute renal failure. Kidney Int. 2007; 72(2): 208-12.

PubMed Abstract | Publisher Full Text | Free Full Text

6. Baba M, Shimbo T, Horio M, et al.: Longitudinal Study of the Decline in Renal Function in Healthy Subjects. PLoS One. 2015; 10(6): e0129036.

PubMed Abstract | Publisher Full Text | Free Full Text

7. Basile DP, Anderson MD, Sutton TA: Pathophysiology of acute kidney injury. Compr Physiol. 2012; 2(2): 1303-53.

PubMed Abstract | Publisher Full Text | Free Full Text

8. O'Kane D, Baldwin GS, Bolton DM, et al:: Preconditioning against renal ischaemia reperfusion injury: The failure to translate to the clinic. $J$ Nephrol. 2019; 32(4): 539-47.

PubMed Abstract | Publisher Full Tex

9. $\quad \mathrm{F}$ Mitchell JR, Verweij M, Brand K, et al.: Short-term dietary restriction and fasting precondition against ischemia reperfusion injury in mice. Aging Cell. 2010; 9(1): 40-53.

PubMed Abstract | Publisher Full Text | Free Full Text | F1000 Recommendation

10. Johnsen M, Späth MR, Denzel MS, et al.: Oral Supplementation of Glucosamine Fails to Alleviate Acute Kidney Injury in Renal Ischemia-Reperfusion Damage. PLoS One. 2016; 11(8): e0161315.

PubMed Abstract | Publisher Full Text | Free Full Text

11. Owji SM, Nikeghbal E, Moosavi SM: Comparison of ischaemia-reperfusioninduced acute kidney injury by clamping renal arteries, veins or pedicles in anaesthetized rats. Exp Physiol. 2018; 103(10): 1390-1402.

PubMed Abstract | Publisher Full Text

12. Späth MR, Bartram MP, Palacio-Escat N, et al.: The proteome microenvironment determines the protective effect of preconditioning in cisplatin-induced acute kidney injury. Kidney Int. 2019; 95(2): 333-349.

PubMed Abstract | Publisher Full Text

13. Yang $Y, Y u X, Z$ Zhang $Y$, et al.: Hypoxia-inducible factor prolyl hydroxylase inhibitor roxadustat (FG-4592) protects against cisplatin-induced acute kidney injury. Clin Sci (Lond). 2018; 132(7): 825-838.

PubMed Abstract | Publisher Full Text

14. Dugbartey GJ, Bouma HR, Lobb I, et al.: Hydrogen sulfide: A novel nephroprotectant against cisplatin-induced renal toxicity. Nitric Oxide. 2016; 57 15-20.

PubMed Abstract | Publisher Full Text

15. Bein B, Meybohm P: [Organ protection by conditioning]. Anasthesiol Intensivmed Notfallmed Schmerzther. 2010; 45(4): 254-61; quiz 262.

PubMed Abstract | Publisher Full Text

16. F Murry CE, Jennings RB, Reimer KA: Preconditioning with ischemia: a delay of lethal cell injury in ischemic myocardium. Circulation. 1986; 74(5): 1124-36. PubMed Abstract | Publisher Full Text | F1000 Recommendation

17. F Przyklenk K, Bauer B, Ovize M, et al.: Regional ischemic 'preconditioning' protects remote virgin myocardium from subsequent sustained coronary occlusion. Circulation. 1993; 87(3): 893-9.

PubMed Abstract | Publisher Full Text | F1000 Recommendation

18. Wang GL, Jiang BH, Rue EA, et al:: Hypoxia-inducible factor 1 is a basic-helixloop-helix-PAS heterodimer regulated by cellular $\mathrm{O} 2$ tension. Proc Natl Acad SciU S A. 1995; 92(12): 5510-4

PubMed Abstract | Publisher Full Text | Free Full Text

19. Bernhardt WM, Câmpean V, Kany S, et al:: Preconditional activation of hypoxiainducible factors ameliorates ischemic acute renal failure. J Am Soc Nephrol. 2006; 17(7): 1970-8.

PubMed Abstract | Publisher Full Text

20. Stokfisz K, Ledakowicz-Polak A, Zagorski M, et al:: Ischaemic preconditioning - Current knowledge and potential future applications after $\mathbf{3 0}$ years of experience. Adv Med Sci. 2017; 62(2): 307-16. PubMed Abstract | Publisher Full Text

21. F Heusch G: Molecular basis of cardioprotection: signal transduction in ischemic pre-, post-, and remote conditioning. Circ Res. 2015; 116(4): 674-99. PubMed Abstract | Publisher Full Text | F1000 Recommendation

22. Weiss $\mathrm{JN}$, Korge $\mathrm{P}$, Honda $\mathrm{HM}$, et al:: Role of the mitochondrial permeability transition in myocardial disease. Circ Res. 2003; 93: 292-301. PubMed Abstract | Publisher Full Text

23. Downey JM, Davis AM, Cohen MV: Signaling pathways in ischemic preconditioning. Heart Fail Rev. 2007; 12(3-4): 181-8. PubMed Abstract | Publisher Full Text

24. Burley DS, Hamid SA, Baxter GF: Cardioprotective actions of peptide hormones in myocardial ischemia. Heart Fail Rev. 2007; 12(3-4): 279-91. PubMed Abstract | Publisher Full Text

25. Costa ADT, Garlid KD: Intramitochondrial signaling: interactions among mitoKATP, PKCepsilon, ROS, and MPT. Am J Physiol Heart Circ Physiol. 2008; 295(2): H874-82.

PubMed Abstract | Publisher Full Text | Free Full Text

26. Boengler K, Schlüter K-D, Schermuly RT, et al:: Cardioprotection in right heart failure. Br J Pharmacol. 2020.

PubMed Abstract | Publisher Full Text

27. Hausenloy DJ, Yellon DM: Reperfusion injury salvage kinase signalling: taking a RISK for cardioprotection. Heart Fail Rev. 2007; 12(3-4): 217-34. PubMed Abstract | Publisher Full Text

28. Przyklenk K, Maynard M, Darling CE, et al.: Aging mouse hearts are refractory 
to infarct size reduction with post-conditioning. J Am Coll Cardiol. 2008; 51(14) 1393-8

PubMed Abstract | Publisher Full Text

29. Annachhatre A, Annachhatre S: Preconditioning in cardiac anesthesia..... where are we? Ann Card Anaesth. 2019; 22(4): 412 PubMed Abstract | Publisher Full Text | Free Full Text

30. Lecour S, Suleman N, Deuchar GA, et al.: Pharmacological preconditioning with tumor necrosis factor- $\alpha$ activates signal transducer and activator of transcription-3 at reperfusion without involving classic prosurvival kinases (Akt and extracellular signal-regulated kinase). Circulation. 2005; 112(25): 3911-8.

PubMed Abstract | Publisher Full Text

31. Boengler K, Hilfiker-Kleiner D, Drexler $\mathrm{H}$, et al:: The myocardial JAK/STAT pathway: from protection to failure. Pharmacol Ther. 2008; 120(2): 172-85. PubMed Abstract | Publisher Full Text

32. Nadtochiy SM, Redman E, Rahman I, et al.: Lysine deacetylation in ischaemic preconditioning: the role of SIRT1. Cardiovasc Res. 2011; 89(3): 643-9. PubMed Abstract | Publisher Full Text | Free Full Text

33. Basheer WA, Fu Y, Shimura D, et al:: Stress response protein GJA120k promotes mitochondrial biogenesis, metabolic quiescence, and cardioprotection against ischemia/reperfusion injury. JCl Insight. 2018; 3(20). PubMed Abstract | Publisher Full Text | Free Full Text

34. Gho BCG, Schoemaker RG, van den Doel MA, et al:: Myocardial Protection by Brief Ischemia in Noncardiac Tissue. Circulation. 1996; 94(9): 2193-200. PubMed Abstract | Publisher Full Text

35. Konstantinov IE, Arab S, Kharbanda RK, et al.: The remote ischemic preconditioning stimulus modifies inflammatory gene expression in humans. Physiol Genomics. 2004; 19(1): 143-50. PubMed Abstract | Publisher Full Text

36. Ding YF, Zhang MM, He RR: Role of renal nerve in cardioprotection provided by renal ischemic preconditioning in anesthetized rabbits. Sheng Li Xue BaO. 2001; 53(1): 7-12.

PubMed Abstract

37. F Olenchock BA, Moslehi J, Baik AH, et al.: EGLN1 Inhibition and Rerouting of $\alpha$-Ketoglutarate Suffice for Remote Ischemic Protection. Cell. 2016; 164(5): 884-95.

PubMed Abstract | Publisher Full Text | Free Full Text | F1000 Recommendation

38. Küntscher MV, Kastell T, Altmann J, et al:: Acute remote ischemic preconditioning II: The role of nitric oxide. Microsurgery. 2002; 22(6): 227-31. PubMed Abstract | Publisher Full Text

39. Brandenburger T, Huhn R, Galas A, et al:: Remote ischemic preconditioning preserves Connexin $\mathbf{4 3}$ phosphorylation in the rat heart in vivo. $J$ Transl Med. 2014; 12: 228.

PubMed Abstract | Publisher Full Text | Free Full Text

40. Albrecht M, Zitta K, Bein B, et al.: Remote ischemic preconditioning regulates HIF-1a levels, apoptosis and inflammation in heart tissue of cardiosurgical patients: A pilot experimental study. Basic Res Cardiol. 2013; 108(1): 314. PubMed Abstract | Publisher Full Text

41. F Er F, Nia AM, Dopp H, et al.: Ischemic preconditioning for prevention of contrast medium-induced nephropathy: randomized pilot RenPro Trial (Rena Protection Trial). Circulation. 2012; 126(3): 296-303. PubMed Abstract | Publisher Full Text | F1000 Recommendation

42. F Roubille F, Macia J-C, Ivanes F, et al.: Effects of remote ischemic conditioning on kidney injury in at-risk patients undergoing elective coronary angiography (PREPARE study): a multicenter, randomized clinical trial. Sci Rep. 2019; 9(1): 11985.

PubMed Abstract | Publisher Full Text | Free Full Text | F1000 Recommendation

43. F Wilhelm-Leen E, Montez-Rath ME, Chertow G: Estimating the Risk of Radiocontrast-Associated Nephropathy. J Am Soc Nephrol. 2017; 28(2): 653-9. PubMed Abstract | Publisher Full Text | Free Full Text | F1000 Recommendation

44. F Zarbock A, Schmidt C, van Aken $\mathrm{H}$, et al.: Effect of remote ischemic preconditioning on kidney injury among high-risk patients undergoing cardiac surgery: a randomized clinical trial. JAMA. 2015; 313(21): 2133-41. PubMed Abstract | Publisher Full Text | F1000 Recommendation

45. F Meybohm P, Bein B, Brosteanu O, et al.: A Multicenter Trial of Remote Ischemic Preconditioning for Heart Surgery. N Engl J Med. 2015; 373(15): 1397-407.

PubMed Abstract | Publisher Full Text | F1000 Recommendation

46. F Hausenloy DJ, Candilio L, Evans R, et al:: Remote Ischemic Preconditioning and Outcomes of Cardiac Surgery. N Engl J Med. 2015; 373(15): 1408-17. PubMed Abstract | Publisher Full Text | F1000 Recommendation

47. Nashef S, Roques F, Hammill BG, et al:: Validation of European System for Cardiac Operative Risk Evaluation (EuroSCORE) in North American cardiac surgery. Eur J Cardiothorac Surg. 2002; 22(1): 101-5. PubMed Abstract | Publisher Full Text

48. Nashef SAM, Roques F, Michel P, et al:: European system for cardiac operative risk evaluation (EurosCORE). Eur J Cardiothorac Surg. 1999; 16(1): 9-13. PubMed Abstract | Publisher Full Text

49. de Hert S, Moerman A: Anesthetic Preconditioning: Have We Found the Holy Grail of Perioperative Cardioprotection? J Cardiothorac Vasc Anesth. 2018;
32(3): 1135-6.

PubMed Abstract | Publisher Full Text

50. Raphael J, Rivo J, Gozal Y: Isoflurane-induced myocardial preconditioning is dependent on phosphatidylinositol-3-kinase/Akt signalling. Br J Anaesth. 2005; 95(6): 756-63.

PubMed Abstract | Publisher Full Text

51. F Deferrari G, Bonanni A, Bruschi M, et al.: Remote ischaemic preconditioning for renal and cardiac protection in adult patients undergoing cardiac surgery with cardiopulmonary bypass: Systematic review and meta-analysis of randomized controlled trials. Nephrol Dial Transplant. 2018; 33(5): 813-24. PubMed Abstract | Publisher Full Text | F1000 Recommendation

52. Gidday JM, Fitzgibbons JC, Shah AR, et al:: Neuroprotection from ischemic brain injury by hypoxic preconditioning in the neonatal rat. Neurosci Lett. 1994; 168(1-2): 221-4.

PubMed Abstract | Publisher Full Text

53. F Semenza GL: Pharmacologic Targeting of Hypoxia-Inducible Factors. Annu Rev Pharmacol Toxicol. 2019; 59: 379-403.

PubMed Abstract | Publisher Full Text | F1000 Recommendation

54. Wenger RH, Stiehl DP, Camenisch G: Integration of oxygen signaling at the consensus HRE. Sci STKE. 2005; 2005(306): re12.

PubMed Abstract | Publisher Full Text

55. Bishop T, Ratcliffe PJ: HIF hydroxylase pathways in cardiovascular physiology and medicine. Circ Res. 2015; 117(1): 65-79.

PubMed Abstract | Publisher Full Text | Free Full Text

56. Dhillon S: Roxadustat: First Global Approval. Drugs. 2019; 79(5): 563-72. PubMed Abstract | Publisher Full Text

57. Chen N, Hao C, Peng X, et al.: Roxadustat for Anemia in Patients with Kidney Disease Not Receiving Dialysis. N Engl J Med. 2019; 381(11): 1001-10. PubMed Abstract | Publisher Full Text

58. Chen N, Hao C, Liu B-C, et al:: Roxadustat Treatment for Anemia in Patients Undergoing Long-Term Dialysis. N Engl J Med. 2019; 381(11): 1011-22. PublMed Abstract | Publisher Full Text

59. Coyne DW, Roger SD, Shin SK, et al:: ANDES: A Phase 3, Randomized, DoubleBlind, Placebo Controlled Study of the Efficacy and Safety of Roxadustat for the Treatment of Anemia in CKD Patients Not on Dialysis (Abstract at kidney week). J Am Soc Nephrol. 2019; 30: 822-823. Reference Source

60. Charytan C, Manllo-Karim R, Martin ER, et al.: SIERRAS: A Phase 3, Open-Label, Randomized, Active-Controlled Study of the Efficacy and Safety of Roxadusta in the Maintenance Treatment of Anemia in Subjects with ESRD on Stable Dialysis (Abstract at kidney week). J Am Soc Nephrol. 2019; 30: 822. Reference Source

61. Fishbane S, El-Shahawy MA, Pecoits-Filho R, et al:: OLYMPUS: A Phase 3, Randomized, Double-Blind, Placebo-Controlled, International Study of Roxadustat Efficacy in Patients with Non-Dialysis-Dependent (NDD) CKD and Anemia (Abtract at kidney week). J Am Soc Nephro. 2019; 30: 6.

62. McCay CM, Crowell MF, Maynard LA: The Effect of Retarded Growth Upon the Length of Life Span and Upon the Ultimate Body Size: One Figure. J Nutr. 1935; 10(1): 63-79.

Publisher Full Text

63. F Colman RJ, Anderson RM, Johnson SC, et al.: Caloric restriction delays disease onset and mortality in rhesus monkeys. Science. 2009; 325(5937): 201-4.

PubMed Abstract | Publisher Full Text | Free Full Text | F1000 Recommendation

64. F Fontana L, Partridge L: Promoting health and longevity through diet: from model organisms to humans. Cell. 2015; 161(1): 106-18.

PubMed Abstract | Publisher Full Text | Free Full Text | F1000 Recommendation

65. Kim CH, Lee EK, Choi YJ, et al:: Short-term calorie restriction ameliorates genomewide, age-related alterations in DNA methylation. Aging Cell. 2016; 15(6): 1074-81.

PubMed Abstract | Publisher Full Text | Free Full Text

66. $\mathrm{F}$ Tiku V, Jain $\mathrm{C}, \operatorname{Raz} \mathrm{Y}$, et al.: Small nucleoli are a cellular hallmark of longevity. Nat Commun. 2017; 8: 16083.

PubMed Abstract | Publisher Full Text | Free Full Text | F1000 Recommendation

67. McKiernan SH, Tuen VC, Baldwin $\mathrm{K}$, et al: Adult-onset calorie restriction delays the accumulation of mitochondrial enzyme abnormalities in aging rat kidney tubular epithelial cells. Am J Physiol Renal Physiol. 2007; 292(6): F1751-60. PubMed Abstract | Publisher Full Text

68. Lee C, Safdie FM, Raffaghello L, et al:: Reduced levels of IGF-I mediate differential protection of normal and cancer cells in response to fasting and improve chemotherapeutic index. Cancer Res. 2010; 70(4): 1564-72. PubMed Abstract | Publisher Full Text | Free Full Text

69. Harputlugil $E$, Hine $C$, Vargas D, et al:: The TSC complex is required for the benefits of dietary protein restriction on stress resistance in vivo. Cell Rep. 2014; 8(4): 1160-70.

PubMed Abstract | Publisher Full Text | Free Full Text

70. F Yu D, Tomasiewicz JL, Yang SE, et al.: Calorie-Restriction-Induced Insulin Sensitivity Is Mediated by Adipose mTORC2 and Not Required for Lifespan Extension. Cell Rep. 2019; 29(1): 236-248.e3.

PubMed Abstract | Publisher Full Text | Free Full Text | F1000 Recommendation 
71. F Arabi YM, Aldawood AS, Haddad SH, et al:: Permissive Underfeeding or Standard Enteral Feeding in Critically III Adults. N Engl J Med. 2015; 372(25): 2398-408

PubMed Abstract | Publisher Full Text | F1000 Recommendation

72. Arabi $Y$, Jawdat $D$, Bouchama $A$, et al.: Permissive underfeeding, cytokine profiles and outcomes in critically ill patients. PLoS One. 2019; 14(1): e0209669. PubMed Abstract | Publisher Full Text | Free Full Text

73. Jongbloed F, de Bruin RW, Klaassen RA, et al:: Short-Term Preoperative Calorie and Protein Restriction Is Feasible in Healthy Kidney Donors and Morbidly Obese Patients Scheduled for Surgery. Nutrients. 2016; 8(5): pii: E306. PubMed Abstract | Publisher Full Text | Free Full Text

74. van Ginhoven TM, de Bruin RW, Timmermans M, et al:: Pre-operative dietary restriction is feasible in live-kidney donors. Clin Transplant. 2011; 25(3): 486-94. PubMed Abstract | Publisher Full Text

75. Grundmann F, Müller RU, Reppenhorst A, et al.: Preoperative Short-Term Calori Restriction for Prevention of Acute Kidney Injury After Cardiac Surgery: A Randomized, Controlled, Open-Label, Pilot Trial. J Am Heart Assoc. 2018; 7(6): pii: e008181.

PubMed Abstract | Publisher Full Text | Free Full Text

76. Grundmann F, Müller RU, Hoyer-Allo KJR, et al.: Dietary restriction for prevention of contrast-induced acute kidney injury in patients undergoing percutaneous coronary angiography: a randomized controlled trial. Sci Rep. 2020; 10: 5202. Publisher Full Text

77. Robertson LT, Treviño-Villarreal JH, Mejia P, et al.: Protein and Calorie Restriction Contribute Additively to Protection from Renal Ischemia Reperfusion Injury Partly via Leptin Reduction in Male Mice. J Nutr. 2015; 145(8): 1717-27.

PubMed Abstract | Publisher Full Text | Free Full Text

78. Guo F, Cavener DR: The GCN2 elF2alpha kinase regulates fatty-acid homeostasis in the liver during deprivation of an essential amino acid. Cell Metab. 2007; 5(2): 103-14.

PubMed Abstract | Publisher Full Text

79. Kamata S, Yamamoto J, Kamijo K, et al:: Dietary deprivation of each essentia amino acid induces differential systemic adaptive responses in mice. Mol Nutr Food Res. 2014; 58(6): 1309-21. PubMed Abstract | Publisher Full Text

80. Peng W, Robertson L, Gallinetti J, et al.: Surgical stress resistance induced by single amino acid deprivation requires Gcn2 in mice. Sci Transl Med. 2012; 4(118): 118ra11-118ra11

PubMed Abstract | Publisher Full Text | Free Full Text

81. $\mathrm{F}$ Hine $\mathrm{C}$, Harputlugil $\mathrm{E}$, Zhang $\mathrm{Y}$, et al:: Endogenous hydrogen sulfide production is essential for dietary restriction benefits. Cell. 2015; 160(1-2): 132-44.

PubMed Abstract | Publisher Full Text | Free Full Text | F1000 Recommendation

82. F Jongbloed F, Saat TC, Verweij M, et al:: A signature of renal stress resistance induced by short-term dietary restriction, fasting, and protein restriction. Sci Rep. 2017; 7: 40901.

PubMed Abstract | Publisher Full Text | Free Full Text | F1000 Recommendation

83. Wang WJ, Cai GY, Ning YC, et al:: Hydrogen sulfide mediates the protection of dietary restriction against renal senescence in aged F344 rats. Sci Rep. 2016; 6: 30292.

PubMed Abstract | Publisher Full Text | Free Full Tex

84. $F$ Yang G, Wu L, Jiang B, et al.: $\mathrm{H}_{2} \mathbf{S}$ as a physiologic vasorelaxant: hypertension in mice with deletion of cystathionine gamma-lyase. Science. 2008; 322(5901): 587-90.

PubMed Abstract | Publisher Full Text | Free Full Text | F1000 Recommendation

85. Miller DL, Roth MB: Hydrogen sulfide increases thermotolerance and lifespan in Caenorhabditis elegans. Proc Natl Acad Sci U S A. 2007; 104(51): 20618-22. PubMed Abstract | Publisher Full Text | Free Full Text

86. Sparatore A, Santus G, Giustarini D, et al.: Therapeutic potential of new hydrogen sulfide-releasing hybrids. Expert Rev Clin Pharmacol. 2014; 4(1): 109-21.

PubMed Abstract | Publisher Full Text

87. Orentreich $\mathrm{N}$, Matias JR, DeFelice $\mathrm{A}$, et al.: Low methionine ingestion by rats extends life span. $J$ Nutr. 1993; 123(2): 269-74. PubMed Abstract

88. Longo VD, Mattson MP: Fasting: molecular mechanisms and clinical applications. Cell Metab. 2014; 19(2): 181-92. PubMed Abstract | Publisher Full Text | Free Full Text

89. F Cheng CW, Villani V, Buono R, et al:: Fasting-Mimicking Diet Promotes Ngn3-Driven $\beta$-Cell Regeneration to Reverse Diabetes. Cell. 2017; 168(5): 775-788.e12.

PubMed Abstract | Publisher Full Text | Free Full Text | F1000 Recommendation

90. Wei M, Brandhorst S, Shelehchi M, et al.: Fasting-mimicking diet and markers/ risk factors for aging, diabetes, cancer, and cardiovascular disease. Sci Trans/ Med. 2017; 9(377): pii: eaai8700.

PubMed Abstract | Publisher Full Text | Free Full Text

91. Choi IY, Piccio L, Childress P, et al.: A Diet Mimicking Fasting Promotes Regeneration and Reduces Autoimmunity and Multiple Sclerosis Symptoms. Cell Rep. 2016; 15(10): 2136-46.

PubMed Abstract | Publisher Full Text | Free Full Text
92. Stranahan AM, Mattson MP: Recruiting adaptive cellular stress responses for successful brain ageing. Nat Rev Neurosci. 2012; 13(3): 209-16.

PubMed Abstract | Publisher Full Text | Free Full Text

93. Dong D, Cai GY, Ning YC, et al:: Alleviation of senescence and epithelialmesenchymal transition in aging kidney by short-term caloric restriction and caloric restriction mimetics via modulation of AMPK/mTOR signaling. Oncotarget. 2017; 8(10): 16109-21.

PubMed Abstract | Publisher Full Text | Free Full Text

94. Saxton RA, Sabatini DM: mTOR Signaling in Growth, Metabolism, and Disease. Cell. 2017; 168(6): 960-76.

PubMed Abstract | Publisher Full Text | Free Full Text

95. Mizushima N, Levine B, Cuervo AM, et al.: Autophagy fights disease through cellular self-digestion. Nature. 2008; 451(7182): 1069-75.

PubMed Abstract | Publisher Full Text | Free Full Text

96. Brown-Borg HM, Buffenstein R: Cutting back on the essentials: Can manipulating intake of specific amino acids modulate health and lifespan? Ageing Res Rev. 2017; 39: 87-95.

PubMed Abstract | Publisher Full Text | Free Full Text

97. Fontana L, Cummings NE, Arriola Apelo SI, et al.: Decreased Consumption of Branched-Chain Amino Acids Improves Metabolic Health. Cell Rep. 2016; 16(2): 520-30.

PubMed Abstract | Publisher Full Text | Free Full Text

98. F Solon-Biet SM, McMahon AC, Ballard JW, et al:: The ratio of macronutrients, not caloric intake, dictates cardiometabolic health, aging, and longevity in ad libitum-fed mice. Cell Metab. 2014; 19(3): 418-30.

PubMed Abstract | Publisher Full Text | Free Full Text | F1000 Recommendation

99. F Solon-Biet SM, Cogger VC, Pulpitel T, et al.: Branched chain amino acids impact health and lifespan indirectly via amino acid balance and appetite control. Nat Metab. 2019; 1(5): 532-45.

PubMed Abstract | Publisher Full Text | Free Full Text | F1000 Recommendation

100. F Wang TJ, Larson MG, Vasan RS, et al:: Metabolite profiles and the risk of developing diabetes. Nat Med. 2011; 17(4): 448-53.

PubMed Abstract | Publisher Full Text | Free Full Text | F1000 Recommendation

101. F Juricic P, Grönke S, Partridge L: Branched-Chain Amino Acids Have Equivalent Effects to Other Essential Amino Acids on Lifespan and Aging-Related Traits in Drosophila. J Gerontol A Biol Sci Med Sci. 2020; 75(1): 24-31.

PubMed Abstract | Publisher Full Text | Free Full Text | F1000 Recommendation

102. Solon-Biet SM, Walters KA, Simanainen UK, et al.: Macronutrient balance, reproductive function, and lifespan in aging mice. Proc Natl Acad Sci U S A. 2015; 112(11): 3481-6.

PubMed Abstract | Publisher Full Text | Free Full Text

103. $\mathrm{F}$ Lee SJ, Murphy CT, Kenyon C: Glucose shortens the life span of $C$. elegans by downregulating DAF-16/FOXO activity and aquaporin gene expression. $\mathrm{Cel}$ Metab. 2009; 10(5): 379-91.

PubMed Abstract | Publisher Full Text | Free Full Text | F1000 Recommendation

104. Verweij M, van de Ven M, Mitchell JR, et al.: Glucose supplementation does not interfere with fasting-induced protection against renal ischemia/reperfusion injury in mice. Transplantation. 2011; 92(7): 752-8. PubMed Abstract | Publisher Full Text

105. Roberts MN, Wallace MA, Tomilov AA, et al.: A Ketogenic Diet Extends Longevity and Healthspan in Adult Mice. Cell Metab. 2017; 26(3): 539-546.e5 PubMed Abstract | Publisher Full Text | Free Full Text

106. F Shimazu T, Hirschey MD, Newman J, et al:: Suppression of oxidative stress by $\beta$-hydroxybutyrate, an endogenous histone deacetylase inhibitor. Science. 2013; 339(6116): 211-4.

PubMed Abstract | Publisher Full Text | Free Full Text | F1000 Recommendation

107. Neal EG, Chaffe H, Schwartz RH, et al:: The ketogenic diet for the treatment of childhood epilepsy: A randomised controlled trial. Lancet Neurol. 2008; 7(6): 500-6.

PubMed Abstract | Publisher Full Text

108. F Torres JA, Kruger SL, Broderick C, et al.: Ketosis Ameliorates Renal Cyst Growth in Polycystic Kidney Disease. Cell Metab. 2019; 30(6): 1007-1023.e5. PubMed Abstract | Publisher Full Text | Free Full Text | F1000 Recommendation

109. Kim JY, Park JH, Kim K, et al.: Pharmacological Inhibition of Caspase-1 Ameliorates Cisplatin-Induced Nephrotoxicity through Suppression of Apoptosis, Oxidative Stress, and Inflammation in Mice. Mediators Inflamm. 2018; 2018: 6571676

PubMed Abstract | Publisher Full Text | Free Full Text

110. Huang S, You J, Wang K, et al:: $\mathbf{N}$-Acetylcysteine Attenuates Cisplatin-Induced Acute Kidney Injury by Inhibiting the C5a Receptor. Biomed Res Int. 2019; 2019 : 4805853.

PubMed Abstract | Publisher Full Text | Free Full Text

111. Späth MR, Hoyer-Allo KJR, Bohl K, et al.: Deciphering the Molecular Mechanisms Underlying Nephroprotection by Hypoxia-Signalling: A Comparative Analysis of Prolyl Hydroxylase Inhibition and Hypoxic Preconditioning (Abstract at kidney week). J Am Soc Nephrol. 2019; 30: 786.

112. Johnsen M, Kubacki T, Yeroslaviz A, et al.: The Integrated RNA Landscape of Renal Preconditioning against Ischemia-Reperfusion Injury. J Am Soc Nephrol. 2020. pii: ASN.2019050534

PubMed Abstract | Publisher Full Text 


\section{Open Peer Review}

\section{Current Peer Review Status:}

\section{Editorial Note on the Review Process}

Faculty Reviews are review articles written by the prestigious Members of Faculty Opinions. The articles are commissioned and peer reviewed before publication to ensure that the final, published version is comprehensive and accessible. The reviewers who approved the final version are listed with their names and affiliations.

\section{The reviewers who approved this article are:}

\section{Version 1}

\section{David Basile}

Department of Anatomy, Cell Biology \& Physiology and the Division of Nephrology, Indiana University, Indianapolis, IN, USA

Competing Interests: No competing interests were disclosed.

\section{James Mitchell}

Department of Genetics and Complex Diseases, Harvard University, Boston, MA, USA

Competing Interests: No competing interests were disclosed.

The benefits of publishing with F1000Research:

- Your article is published within days, with no editorial bias

- You can publish traditional articles, null/negative results, case reports, data notes and more

- The peer review process is transparent and collaborative

- Your article is indexed in PubMed after passing peer review

- Dedicated customer support at every stage

For pre-submission enquiries, contact research@f1000.com 